\title{
The Rise and Fall Of Turkish Soft Power and Public Diplomacy
}

\author{
Türk Yumuşak Güç ve Kamu Diplomasisinin Yükseliş \\ ve Düşüşü
}

\author{
Muharrem EKŞi* - Mehmet Seyfettin EROL**
}

\begin{abstract}
This article explores Turkey's public diplomacy and soft power policies under the government of the Justice and Development Party (JDP) over the period of 2003 to 2016. Thus, Turkish foreign policy is analysed within the framework of soft power policy and the new institutional design of the country's public diplomacy. The main research questions of the study are as follows: "What are Turkey's public diplomacy mechanisms and instruments, and furthermore, why did Turkey begin to implement public diplomacy under the JDP governments? Additionally, how does Turkey implement soft power policies in line with the new foreign policy doctrine?" The study has two fundamental arguments: First, the JDP leaders' ambition to become a regional power and the leader of the Middle East and Muslim world has played the chief role in pushing forward with public diplomacy and soft power policies. Secondly, the new vision and identity of the ruling party leaders have been effective in the transformation process for a shift towards soft power and public diplomacy in new foreign policy doctrine within a modern understanding. In this context, the JDP rule initiated public diplomacy and soft power policies until the Arab Spring, which era could characterize the rise of Turkish soft power. However, Turkish soft power began to fall particularly in the wake of the Syrian crisis.
\end{abstract}

Keywords: Public Diplomacy, Soft Power, AK Party, Turkish Foreign Policy, Middle East.

\section{Öz}

Bu makale 2003-2016 yıllari arasindaki AK Parti döneminde uygulanan Türkiye'nin kamu diplomasisi ve yumuşak güç politikalarını analiz etmektedir. Bu bağlamda araştırmada yumuşak güç kavramı ve kamu diplomasisinin yeni kurumsal mekanizmaları çerçevesinde Türk dış politikasının analiz edilmesi yöntemi uygulanmıştır. Bu çalışma için şu temel araştırma sorular belirlenmiştir: Türkiye'nin kamu diplomasisi mekanizmaları ve araçları nelerdir?, Neden Türkiye, AK Parti döneminde kamu diplomasisi politikası uygulama gereğini duymuştur?, ayrıca Türkiye, yumuşak güç politikasııı nasıl yeni dış politika doktrini düzleminde uygulamıştır? Bu çerçevede iki temel argüman geliştirilmiştir: Birincisi, kamu diplomasisi ve yumuşak güç politikalarının uygulanmasını sağlayan motivasyon, AK Parti liderlerinin Müslüman Ortadoğu'da bölgesel güç ve İlam dünyasının lideri olma ideali olmuştur. İkincisi, AK Parti liderlerinin yeni vizyon ve kimliği, kamu diplomasisi ve yumuşak güç temelli dış politika doktrinini dönüştürmüştür. Arap Baharı sürecine kadar AK Parti hükü̈metleri, kamu diplomasisi ve yumuşak güç politikalarını uygulamıştır. Ancak Suriye krizi, Türkiye'nin komşularla sifır sorun, serbest ticaret bölgesi inşa etme gibi yumuşak güç politikalarının sonunu getirmiştir. Bundan sonra hükü̈metin sert güç politikalarını uygulamaya geçmesiyle birlikte Türk dış politikasında 2003 ile 2011 arası yürsselişte olan yumuşak gücün düşüşü başlamıştır.

Anahtar Kelimeler: Kamu Diplomasisi, Yumuşak Gǚs, AK Parti, Türk Diş Politikası, Ortadoğu.

Makale Geliş Tarihi: 16.06.2018, Makale Kabul Tarihi: 29.09.2018

* Assoc. Prof., International Relations, Kırklareli University, e-mail: eksimuharrem@gmail.com

** Prof. Dr., International Relations, Gazi University, e-mail: mserol@gmail.com 


\section{Introduction to the New Turkish Foreign Policy within the Framework of Soft Power and Public Diplomacy}

The Justice and Development Party (JDP) government began to implement diplomacy within the framework of the diversification of Turkish foreign policy and also initiated soft power policy in order to enhance Turkey's influence in the Balkans, Caucasia, Central Asia, Africa, and in the Middle East. Furthermore, the JDP leaders' desire to become a regional power and the leader of the Middle East and Muslim world played the main role in adopting public diplomacy and soft power policies ${ }^{1}$. Thus, Turkish foreign policy has been diversified both in cultural, historical and societal components and instrumentsmechanisms by public diplomacy. Nevertheless, Turkey reached its limit of its power, capacity and instruments in turn due to Syrian crisis.

This study analyses the implementation of soft power and public diplomacy within Turkish foreign policy under the JDP rule during the 2000s in the reforming the mentality and institutional framework of the country. The main research question of the study is as follows: "Why did Turkey shift towards soft power and implementation of public diplomacy for the first time in 2000s in the JDP era?" The fundamental argument of this question is: The new vision and identity of the ruling party leaders have been effective in the transformation process for a shift towards soft power and public diplomacy in foreign policy within a modern understanding. The JDP cadres, taking their roots from Islamist tradition, aimed for leadership of the Muslim world by using their own Islamic culture and New Turkey's identity ${ }^{2}$. Consequently, the JDP leaders' design required building New Turkey and a new identity and the best way to do this was using soft power and public diplomacy to promote it in the world New Turkey identity was branded as Muslim conservative democracy with nation-branding methodology under the leadership of the JDP and was launched all over the world accordingly ${ }^{3}$. Under the authority of the JDP government, the Muslim conservative identity would be soft power used in the Islamic world to a greater extent and particularly it would focus on the Middle East. The JDP government aimed to achieve this strategic objective via public diplomacy, thereby launching Turkey's new identity in Muslim societies, gaining their sympathy and having them think the JDP's model as a reachable vision for their own country. For this reason, public diplomacy and soft power in Turkish foreign policy was introduced during 2000s decade for the first time with the JDP government ${ }^{4}$. The JDP regime mainly brandished soft power and public diplomacy in the Middle East's politics.

1 Traub, J., "Turkey rules", New York Times, 01.03.2011, http://www.nytimes.com/2011/01/23/ magazine/23davutoglu-t.html?_r=0.

2 Semih İdiz, “Will Islamic world accept Turkey's leadership?”, Al Monitor, 2016,

3 Yalçın Akdoğan, AK parti ve Muhafazakar Demokrasi, İstanbul: Alfa Yayınları, 2004.

4 Muharrem Ekşi, The Rise and Fall of soft Power in Turkish Foreign Policy: The rise and fall of the "Turkish Model' in the Muslim World, Saarbrücken: LAP Lambert Academic Publishing, 2016, s. 26. 
The second eminent research question is why Turkey's soft power has been predominantly directed to the Middle East. In response to this question, three arguments are suggested. First, Turkey set its core foreign policy in the Middle East during the JDP era. This was because the Middle East is within Turkey's geography surroundings and at the same time it was experiencing the most crucial shift in its history. For that reason, Turkey could not stay away from all the critical transformations that were occurring in the Middle East. As a result, Turkey had to deal with the region to a great extent. Because; with the U.S. occupation of Iraq in 2003 Turkey became a neighbour of a superpower. Another reason for the JDP to put the Middle East as a focus of foreign policy was the party's Islamic identity. The JDP's Islamic identity leads it to be connected to the Middle East. In addition to this, the ruling leaders made use of Islamic identity, public diplomacy and other programs to deepen the ties with the Middle Eastern countries. The JDP government conducted identity-based public diplomacy to gain sympathy from Muslim societies by highlighting their Islamic ties and identity in general discourse. Third, model partnership policy developed with the U.S. was an effective way for Turkey to implement soft power policy centring on the Middle East ${ }^{5}$. Accordingly, Turkey was to be viewed as a model country when it came to Muslim Middle Eastern countries by highlighting its traits: being a conservative Muslim democracy, a neoliberal and capitalist developing economy, and at the same time being both a NATO member and a member-candidate country for the EU. In this context, the U.S. implemented a supportive policy with Turkey by opening a space in Middle East until 'Arab Spring'. The JDP government tried to realize their goal of being a model country for the region by practicing public diplomacy with the soft power image. Within this context, Turkey introduced a model country-based public diplomacy towards the Middle East under the JDP rule ${ }^{6}$.

The JDP government initially claimed that it would follow a foreign policy, which was diverged from those of the previous governments and did so by producing new conceptions ${ }^{7}$. The concept of central country was the leading one of these conceptions. With this nation-branding, the ruling government tried to position Turkey in the international system and claimed that Turkey was a naturally central country due to its historical, cultural and geographical position. On the other hand, Ahmet Davutoğlu, the former Minister of Foreign Affairs, argued that Turkey should adopt a multidimensional foreign policy

\section{gers}

Akademik Bakış 17 Cilt 11 Sayı 23 Kış 2018

5 Kadir Ustun and Kılıç Buğra Kanat, “US- Turkey relations: Arab Spring and the search for model partnership", SETA DC Perspective, http://file.setav.org/Files/Pdf/20130515122804_seta_ dc_perspective_ustun_kanat_us_turkey.pdf. 2012,s. 2.

6 Muharrem Ekşi, “AK Parti döneminde Ortadoğu'da Türk-Amerikan ilişkilerinin Jeokültürel Ekseni: İslami kimlik. Gazi Akademik Bakış, 9 (18), 59-77, 2016, s. 73

7 Ahmet Davutoglu, “Turkey's Foreign Policy vision: An assessment of 2007. Insight Turkey, 10(1), 77-96. 
governments $^{8}$. In this context, Turkey implemented a global and multifaceted foreign policy simultaneously in Latin America, Africa, Middle East and China'. This made Turkey a global actor instead of having a unilateral policy that locked it in the West only. Therefore, it started to increase the number of foreign missions and doubled their number from 2002, when it took power, to $2012^{10}$. In addition, Turkey chose to conduct a proactive and rhythmic diplomacy in foreign policy, based on hosting international conferences and having a voice in the global policy-making platforms.

The ruling party began to materialize paradigmatic transformations in the traditional Turkish foreign policy. First, it radically abandoned the Middle East approach of the previous governments of not intervening in the quagmire of the Middle East and developed the Middle Eastern-oriented policy of zero-problem with neighbours. In this framework, the government discovered its policy of first solving the existing problems with the neighbouring Middle Eastern countries and then providing the commercial and political integration ${ }^{11}$. The neighbouring countries responded positively to this approach by Turkey while mutual exchange of visits increased and bilateral free trade agreements started to be concluded. Subsequently, the political relations improved and a bilateral strategic high-level cooperation mechanism was built ${ }^{12}$. Therefore, Turkey's relations with its neighbours, particularly with those in the Middle East, began to remarkably improve and develop at a level never before seen in the history of modern Turkey. The global and regional foreign policy strategies of the JDP government that were very attractive and successful were based primarily upon its soft power policy strategy, which it developed on the basis of its Islamic identity.

\section{The Ruling Party's Vision of Public Diplomacy and Soft Power: Identity-Based Soft Power and Public Diplomacy: Islamic Identity}

The new vision and identity of the JDP leaders ruling the country in the 2000s was effective while Turkey shifted for the first time to the soft power and public diplomacy in foreign policy in a modern and institutional manner. The identity of the JDP that originates from the National Outlook tradition (Milli Görüş), which is an Islamist movement, is one of the most significant characteristics

$8 \quad$ A.g.m. s. 82

9 Mehmet Seyfettin Erol, "11 Eylül sonrası Türk Dış Politikasında vizyon arayışları ve Dört Tarz-1 Siyaset", Gazi Akademik Bakış, 1(1), 33-55, s. 52.

10 KDK, “13 yılda 65 yeni temsilcilik: Türkiye'nin yurtdışındaki temsilcilik sayısı 228'e çıktı”, $K D K, \quad 2015$, http://kdk.gov.tr/sayilarla/13-yilda-65-yeni-temsilcilik-turkiyenin-yurtdisindakitemsilcilik-sayisi-228e-cikti/41.

11 Bülent Aras, "Davutoğlu era in Turkish Foreign Policy", SETA Policy Brief, 32, , s. 9.

12 MFA, "Turkey- GCC high level strategic dialogue meeting of Ministers of Foreign Affairs to be held in İstanbul", T.C. Dışişleri Bakanlı̆̆ı, 2012, http://www.mfa.gov.tr/turkey-gcc-high-levelstrategic-dialogue-meeting-of-ministers-of-foreign-affairs-to-be-held-in-istanbul.en.mfa. 
of the ruling party that distinguishes it from the previous parties with strict secular identity. Yet, the JDP leaders also transformed the National Outlook tradition. It could be even argued that JDP transformed Islam and Islamist movements from radical to moderate in line with the U.S.' Greater Middle East Initiative and Moderate Islam policy in Turkey. In this sense, the Islamist identity of JDP can be defined as a global, neo-liberal and moderate Islam. With its Islamist identity, the government managed to become a model for the Muslim world, while it integrated Islam in globalization on one hand and Muslim bourgeois under the umbrella of MUSİAD (Independent Industrialists' and Businessmen' Association) into capitalism on the other ${ }^{13}$. Beyond that, coming to power as the majority party with Islamist traditions for the first time both in Turkey and the Muslim world provided the party with a privileged position at a global level. This was decisive for the JDP leaders' vision to be a model for the Muslim countries.

Therefore, the ruling party harmonized its Muslim identity with democracy within the framework of "conservative democrats" and wanted to introduce it to the world that it represented a model of what an Islamic movement might accomplish through democratic processes. As suggested by Bilgin Ayata, the JDP government offered an Islamic governance model to the Muslim societies ${ }^{14}$. It could be argued that the JDP leaders reference was the Christian Democratic Party model in Europe when they adopted a strategy of marketing to the whole world, particularly to the Muslim Middle East, the JDP modelled that Islam and democracy could be harmonized ${ }^{15}$. In addition, the government gave preference to employ its model for the Middle East in the form of soft power, as it would otherwise have negative response. It opted to wield soft power discourse since the model concept would cause a perception of hegemony and imperial tendency of Turkey in the Middle East. Notwithstanding, the employment of soft power for embedding model in Middle East became a strategic concept that allowed Turkey to be recognized positively by the countries and communities of the region. At the same time, the government built a vision of implementing and embedding these countries model in foreign policy based upon its soft power due to its Muslim democracy identity. For this purpose, the ruling party built an image of its Muslim identity first by nationbranding method through public diplomacy. Then, the JDP leaders realized a cultural transformation was necessary in foreign policy within the framework of moderate Islam and started to pay attention to use of populist discourse

13 Özlem Tür, "Economic relations with the Middle East under the AKP_Trade, business community and reintegration with neighboring zones", Turkish Studies, 12(4), 201 1, 589-602, s. 591 Bilgin Ayata, "Turkish Foreign Policy in a changing Arab World: Rise and fall of a regional actor?", Journal of European Integration, 37, 95-112, s. 95.

15 William Hale, "Christian Democracy and the AKP: Parallels and contrasts", Turkish Studies, 6(2), 2005, 293-a310, s. 293. 
with a weighted Islamic tone towards the Muslim Middle East in order to address such feelings. They actually intended to win the hearts and minds of the Muslim people of the Middle East. Likewise, another indicator of the identity transformation of the government is the relation with the Muslim world. The JDP leaders developed a policy of relations within the Muslim world for the first time in Turkish foreign policy ${ }^{16}$. In this context, a critical reason why the Middle East gained significance in the ruling party's foreign policy is the proximity of the JDP's leading figures to the Muslim communities in terms of their values, identity and culture. It was aimed with this policy to make sure that Turkey first expands to the markets of the Muslim world and then tries to become the leader of the Muslim world eventually.

In this context, the Muslim identity became the most important element in determining and feeding the vision of the foreign policy of the JDP. Likewise, the ruling government first needed public diplomacy to implement this identity-based policy. Therefore, the government followed the policy of soft power in order to win hearts and mind of the Muslim communities by means of public diplomacy in foreign policy. In this sense, public diplomacy happened to be a strategic instrument for the soft power policies of the JDP government.

\section{Soft Power Policies Policy of Zero-Problem with Neighbours}

The zero-problem policy that inherently intends to lower the security problems reflects the perspective of the JDP government towards the Middle East and the change of mindset. Instead of the traditional standpoint of the former governments that was security-based and which avoided intervention in the region that it regarded to be a quagmire, the government preferred the problemsolving based strategy and de-securitization policy ${ }^{17}$. It adopted the approach of first overcoming the problems and then developing the commercial and political relations ${ }^{18}$. Therefore, the government first changed the rhetoric of Turkey's image in its traditional Middle East approach and later replaced the rigid and security-based approach with soft power and trade-oriented policy through its zero-problem policy. In this framework, the government followed an economic expansion policy by signing free trade agreements with the Middle Eastern countries ${ }^{19}$. Thus, it made a paradigmatic transformation in the traditional Turkish foreign policy. Likewise, concepts within the Middle East

16 Nuri Yesilyurt ve Atay Akdevelioglu, “AKP döneminde Türkiye'nin Ortadoğu Politikası, AKP Kitabı: Bir Dönüşümün Bilançosu, Uzgel, İlhan ve Duru, Bülent (ed.), Ankara: Phoenix, 2009, s. 387.

17 Bülent Sarper Ağır, "Non-traditional security issues of the Western Balkans: Actors, causes and implications", Turkish Yearbook of International Relations, 45, 2014, 65-91, s.91.

18 Meliha Benli Altunışık, "Turkish foreign Policy in the 21st Century”, , 2011, s. 195.

19 Özlem Tür, "Economic relations with the Middle East under the AKP-Trade, business community and reintegration with neighboring zones", Turkish Studies, 12(4), 2011, 589-602, s. 594. 
policy of Turkey like threat, military, power and security were replaced with liberal ones like cooperation, integration, development, partnership and winwin strategy. This rhetoric change was not limited to only new discourses or concepts but transformed the policy by assuming the roles of mediator and facilitator. Hence, the government took on the role of peacekeeper in the "peace" talks between Syria and Israel, in the Palestine and Israel conflict, between Hamas and Fatah, in the nuclear program of Iran, and in the political crisis in Lebanon $^{20}$.

The zero-problem policy manifested itself particularly the relations between Turkey and Syria, which soon resulted in honeymoon-like relations between the two countries. As emphasized by Baskın Oran, the Turkey-Syria relations were always based upon hard power due to the historical problems of the Hatay province, the Euphrates River and the Tigris River ${ }^{21}$. For instance, the two countries were on the verge of a war in 1998 due to the fact that Syria hosted terror organization PKK and its leaders who were responsible for terror attacks in Turkey. But the relations improved after the Adana Protocol of Understanding signed in October 1998. The government utilized this protocol to pursue a policy of overcoming the problems with Syria and improving their relations. Therefore, the JDP leaders proceeded to describe the two societies as brothers in order to show the change in the relationship between the two countries. Further, Turkey launched peacekeeping initiatives as of 2003 to repair the Syria-Israel relations. Turkey also assumed peacekeeping in the Syria-Iraq dispute in 2009. The relationship between the two countries was expeditiously recovering and then it increased even more between 2003 and 2010 that this period was referred in the literature as a honeymoon and golden times $^{22}$. The basic indicators of the development of the relations between the two countries can be listed as mutual frequent visits, bilateral agreements, increasing trade volume and joint vacations of the leaders of the two countries. However, after the Arab Spring spread to Syria, the relationship between the two countries quickly began to deteriorate; Turkey left soft power and returned to hard power strategy in its Syrian policy. The Syrian crisis that emerged with the Arab Spring did not only ruin the Turkey-Syria relations but also terminated the soft power-based foreign policy of the government towards its southern neighbour in the Middle East.

20 Aylin Gürzel, “Turkey's role as a regional and global player and its power capacity: Turkey's engagement with other emerging states", Rev. Sociol. Polit, 22(50), 2014, 95-105, s. 101

21 Baskın Oran (der.), Türk Dış politikası: Kurtuluş savaşından bugüne olgular, belgeler, yorumlar, İstanbul: İletişim Yayınları. 2013, s. 156.

22 Sami Moubayed, “Turkish-Syrian relations: The Erdoğan legacy", SETA DC Policy Brief, 2008, http:// setadc.org/wp-content/uploads/2015/05/SETA_Policy_Brief_No_25_Sami_Moubayed.pdf , s.1. 


\section{Armenian Initiative as Normalization Diplomacy}

Turkey recognized the independence of Armenia in 1991 together with the other former USSR countries, but did not establish diplomatic relations due to the invasion of Nagorno-Karabakh and so-called genocide accusations. Until the JDP rule, the Armenia policy of Turkey was based on the termination of Armenian occupation on the soil of Nagorno-Karabakh of Azerbaijan and abandoning the so-called 'genocide allegations'. The government left the policy with Azerbaijan and so-called genocide in 2009 and initiated unilateral normalization of relations with Armenia. The normalization process began with sports diplomacy when the then President Abdullah Gül went to a football match on 6th September 200823. Later a secret negotiation process was conducted and a bilateral understanding was reached in Switzerland in April 2009. Turkey and Armenia signed the protocols on the 10th of October 2009, with great jubilation as applause was seen from the ministers of foreign affairs of the EU,the USA, Russia and Switzerland.

These protocols instituted the normalization of relations between the two countries ${ }^{24}$. Accordingly, the first protocol would establish diplomatic relations between the two countries and the second would open a common border. Other protocols would set up joint commissions as an attempt to solve the problems between the two countries. It was intended to solve the so-called 'genocide' declaration and criminalizing it in senates and parliaments through the history commission in particular. However, the normalization process failed because both countries followed conventional diplomacy methods instead of public diplomacy. Both countries needed to obtain the consent of their public opinion by explaining to them the normalization process. Turkey needed to use public diplomacy for this normalization process in order to make people understand why they were doing this, even with the Azerbaijan problem still existing, in order to get support for this new policy.

One of the most important reasons behind the blockage of the normalization process might be the solution method of the Minister of Foreign Affairs Davutoğlu, who tried to use the same pragmatic approach for a historically chronic issue between Turkey and Syria when dealing with the Armenian normalization. However, the Turkey-Armenia relations and issues are hinged upon a long history and, therefore, on historical perceptions. For that reason, it was necessary to eliminate these historical prejudices and negative stereotypes and to develop dialogue policies to ensure convergence between the societies. This would only be conceivable by long-term public diplomacy

23 Ömer Engin Lütem, "Türkiye-Ermenistan ilişkilerinin güncel durumu”. Yeni Türkiye, 60, 2014, 1-91, s. 14.

24 MFA, Protocol on development of relations between The Republic of Turkey and The Republic of Armenia. http://www.mfa.gov.tr/site_media/html/zurih-protokolleri-tr.pdf. 
methods. In this context, normalization diplomacy with Armenia should be addressed within the framework of public diplomacy. Ignoring the public diplomacy dimension of the normalization resulted in the blockage of the process and in the degradation of the relationship with Azerbaijan. Therefore, civilian initiatives should have been implemented, and the hostile and negative perceptions of societies towards each other needed to be transformed within the framework of public diplomacy between two communities that have had historical biases. In general, it could be argued that essentially psychological and historical obstacles blocked the ability to overcome the problems between the two countries and communities. This is largely due to the fact that both societies and countries are stuck in 1915. The way to overcome this is to highlight the fact that the history between the two communities does not consist only of 1915 and they have had a long history of living together in peace. In this sense, the history between the two communities and countries should be rebuilt in line with experience of peaceful coexistence in the Ottoman period.

Another problematic dimension of the normalization relations is the attitude of the Armenian diaspora. The Armenian diaspora did not only question the normalization of the relations of these two countries but also caused a great setback as they offended the international image of Turkey by urging legislations to be passed stating Turkey had committed the so-called "genocide" in the countries they live in. A long-term policy particularly including lobby activities among the public diplomacy methods should be developed instead of the ad-hoc system of all governments.

\section{Model Country-Based Public Diplomacy: Model Country Policy toward the Middle East}

The focus and centre of the Turkish foreign policy in 2000s was the Middle East. This was affected by the internal and external dynamics. External factors include the invasion of Iraq in 2003 by the U.S. and the emergence of colossal transformations in the Middle East, while the main internal factor was the fact that a party from an Islamist tradition came to power in Turkey. The will of the JDP to follow a policy based upon the Muslim world by making a virtue of its Islamic identity formed the most significant domestic dynamic of Turkey's tendency towards the Middle East in 2000s. In addition, Turkey became a strategic ally of the U.S. in the Middle East because of its' moderate Islam policy in this period. This led to the Middle East-oriented model partnership policy between Turkey and the USA ${ }^{25}$.

Within this framework, the U.S. followed policies to support Turkey in the Middle East and opened space for Turkey in the region until the Arab Spring. On the other hand, Turkey started to use a discourse with a dominant

25 Jim Zanotti, Turkey: Background and U.S. relations, Congressional Research Service, June 6, 2018, , s.6. 
Islamic tone to open space for itself in the Middle East ${ }^{26}$. This aimed to win the sympathy of the Muslim peoples of the Middle East. Populist discourse policy was actually employed in order to win the hearts and minds of the Muslim societies of the Middle East. In addition, the JDP leaders used their Muslim identity to develop their relations with the Muslim countries of the Middle East ${ }^{27}$. In addition to that, a policy was utilized to criticise Israel to win the support of the Muslim societies ${ }^{28}$. Thus, Turkey followed the strategy of getting closer to the Muslim countries and peoples of the Middle East over Israel. The JDP leaders went further and further in order to become the leaders of the Palestine issue ${ }^{29}$.

On the other hand, Turkey tried to implement its model country policy via the soft power concept in the Middle East by using its Muslim democrat identity of the JDP rule. In other words, the soft power policy of Turkey in the Middle East included its existence as a model country. The JDP leaders preferred to use the soft power discourse in the Middle East policy, since the model country discourse would receive a negative welcome by the countries and people of the Middle East. Turkey did not only use soft power as a discourse but also followed soft power policy with other actions. Within this framework, Turkey concluded visa exemption agreements as well as free trade agreements (FTA) with the Middle East countries to foster its relations. In this context, FTAs were signed with Tunisia and Palestine in 2005, Morocco (2006) with Syria and Egypt in 2007 and with Jordan in $2011^{30}$. In addition, the ruling governments employed the strategy of increasing soft power through trade in the Middle East and established business councils within the countries of the region. In this context, business councils were established in Lebanon in 2002, Saudi Arabia in 2003, Bahrain in 2005; Qatar, Kuwait, Oman in 2006, Libya and Israel in $2007^{31}$. The trade volume of Turkey with the Arab countries increased during the JDP governments by 8 fold from 8 billion USD to 64.2 billion USD through the FTA and business councils ${ }^{32}$. Likewise, the Gulf Co-

Akademik

Bakış

24

Cilt 11

Sayı 23

Kış 2018
26 Seymen Atasoy, "The Turkish example: A model for change in the Middle East?. Middle East Policy,

27 Muharrem Ekşi, The Rise and Fall of soft Power in Turkish Foreign Policy: The rise and fall of the "Turkish Model' in the Muslim World, Saarbrücken: LAP Lambert Academic Publishing, 2016, s. 59.

28 Karol Kujawa, "Turkey and democratization in the Arab World: Between an inspiration and a model", PISM Policy Paper, 2011, https://www.pism.pl/files/?id_plik=8151.

29 Jpost, "Hamas: Erdogan's victory is a victory for Palestine", Jerusalem Post, 2015, http://www. jpost.com/Middle-East/Hamas-leadership-congratulates-Turkeys-Erdogan-431796.

30 Ekonomi Bakanlı̆̆ı, Serbest ticaret anlaşmalarına ilişkin genel bilgi, 2014, T. C. Ekonomi Bakanlığı, http://www.ekonomi.gov.tr/portal/content/conn/UCM/path/Contribution\%20Folders/web/D\%C4\%B1\%C5\%9F\%20\%C4\%B0li\%C5\%9Fkiler/Serbest\%20Ticaret\%20 Anla\%C5\%9Fmalar\%C4\%B1/ekler/sta\%20tablo.pdf?lve.

31 DEIK, Deik iş konseylerinde yeni dönem başliyor", DEIK, 2016, https://www.deik.org.tr/6352/ DE\%C4\%B0K_\%C4\%B0\%C5\%9E_KONSEYLER\%C4\%B0NDE_YEN\%C4\%B0_D\%C3\%96NEM_ BA\%C5\%9ELIYOR.html.

32 TRTHaber, “Türkiye, insani yardımda lider ülke”, TRT Haber, 2016, http://www.trthaber.com/ 
operation Council recognized Turkey as a strategic partner in 2008. After these developments, Turkey established high-level strategic cooperation councils with the Middle East countries to implement its policy to establish a kind of joint cabinet of ministers with the countries of the region ${ }^{33}$. Furthermore, Turkey introduced mediation initiatives in its Middle East policy. As such, Turkey developed a mediation initiative on the basis of sovereignty and control of the Golan Heights between Syria and Israel. Moreover, Turkey proceeded to mediation between Israel and Hamas while playing a role of facilitator for the integration of Hamas into the politics of region and for consensus with Al Fatah. Particularly its achievement of solving the problem of Israeli Soldier Gilad Shalit held hostage by Hamas, the Economist magazine detailed the mediation initiatives of Turkey particularly President Erdogan as a success story under the headline of "the Great Mediator"34.

In addition, the government implemented a public diplomacy based upon model country. Specifically, Turkey implemented a policy of building its Muslim democracy consisting in a free market economy, Western alliance, NATO membership and EU accession process, and soft power in the Middle East. Within the framework of public diplomacy policy rested on attraction through the story of the country and thus distinguishing as a soft power; Turkey followed a strategy to explain its model country peculiarities to the Middle Eastern countries and societies. In fact, the model country rhetoric is hinged upon the story of the JDP, not Turkey ${ }^{35}$. The JDP's story is based first on its transformation from its original Islamist movement to a moderate direction and then on to the transformation of Turkey and its foreign policy ${ }^{36}$. With regard to political Islam that is the fundamental phenomenon of the Middle East politics, the soft power of the JDP in the Middle East was based first on the transformation of political Islam in Turkey and then on the transformation of the Islamic movements in the region and the Muslim countries. In this context, the Western countries supported Turkey, particularly the U.S., as a model country for the Middle East ${ }^{37}$. Turkey followed the model country policy using its soft power rhetoric. In this sense, the Middle East policy of Turkey during

m/?news=darbe-yapacagimizi-abdye-bildirdik\&news_id=212433Ecategory_id=1.

33 KDK, "Yüksek Düzeyli İşbirliği Mekanizmaları", Kamu diplomasisi Koordinatörlüğüu, 2016, http:// kdk.gov.tr/haber/yuksek-duzeyli-isbirligi-mekanizmalari/452.

34 Economist, "The great mediator", The Economist, 2010, http://www.economist.com/ node/16847136.

35 Nil Gülsüm, "AK Parti modeli dünya için şans", Yeni Şafak, 2015, http://www.yenisafak.com/ hayat/ak-parti-modeli-dunya-icin-sans-2143267.

36 Bilal Sambur, "The great transformation of political Islam in Turkey: The case of justice and development party and Erdogan", European Journal of Economic and Political Studies, 2(2), 2009, 117-127. s. 119.

37 T. P. Carrol, “Turkey's justice and development party: A model for democratic Islam?. The Middle East Intelligence Bulletin, 2004, https://www.meforum.org/meib/articles/0407_t1.htm.

Akademik Bakış 25 Cilt 11 Sayı 23 Kış 2018 
the JDP governments can be conceptualized as a model country-based public diplomacy. It is remarkable that such an intervention towards the Middle East policy of Turkey reflects a radical transformation. Hence, until the JDP rule, Turkey's Middle East policy was determined to be non-interventionary in the problems of the region. Former governments considered the Middle East as a quagmire and chose to keep away from it ${ }^{38}$. The proactive policies of the ruling government in the Middle East reflect a radical disengagement from the previous governments, as well as a shift in the central paradigm.

However, the model country-based Middle East policy of Turkey failed because of the Syria crisis and the Arab Spring that began in 2011. This rested upon the fact that the overlapping interest of the U.S and Turkey in the Middle East politics disintegrated after the Arab Spring process. Likewise Turkey was left alone in the Syria crisis, while Syria used to represent the pilot country of the JDP model country policy ${ }^{39}$. On the other hand, it is suggested that the policy of the JDP leaders to turn away their support towards the U.S. and the West which was limited only to the model country, towards its leadership in the Middle East and even in the Muslim world caused the loss of the support of the U.S. and the West as well as the collapse of its Middle East policy. Likewise in the process of Arab Spring and Syria crisis, Turkey left its soft power policy that it had been implemented between 2003 and 2011 and shifted to the hard power policy. In other words, the Syrian crisis brought the soft power policy of Turkey to an end.

\section{The Initiative of Alliance of Civilizations: Global Public Diplomacy Project}

The JDP leaders did not keep the model country rhetoric limited within the Middle East but also tried to utilize it for the leadership of the Muslim world. The Initiative of Alliance of Civilizations, known also as UNAOC, started in 2005 under the auspices of the UN Secretary General Kofi Annan, President Erdogan, and the Spanish Prime Minister José Luis Rodríguez Zapatero. It was used by the JDP government as a global public diplomacy opportunity to try and to become the speaker of the Muslim World. The historic context of the initiative was based upon the discussions of "clash of civilizations" which became a keystone in the agenda of the international public opinion during 1990s. The clash of civilizations argument was brought about to the international public by the article of Huntington and it was depended upon the assumption that the essential dynamics of the post-Cold War conflict would be the conflicts between cultures and religions as a new threat ${ }^{40}$. Huntington established his argument mainly on the conflict between the West and Islam rather than all

38 Ahmet Davutoğlu, Davutoğlu: Ortadoğu'ya bataklık dedirtmeyeceğiz", Yeni Şafak, 2014, .

39 Ibrahim Natil, "Turkey's Foreign policy challenges in the Syrian crisis", Irish Studies in International Affairs, 27, 2016, 1-10, s. 2.

40 Samuel P. Huntington, "The clash of civilizations", Foreign Affairs, 27(3), 1993, ss. 22-49. 
other civilizations. As a result of the escalating controversy and concerns on clash of civilizations, in 1998 UN General Assembly declared the year 2000 as the "Year of Dialogue between Civilizations" upon the proposal of the Iran's President Khatami ${ }^{41}$. However, the terrorist attacks in the U.S. on September 11, 2001 were named by the Bush Administration as "Islamic Terror" and he started a war against the "Islamic" terror that caused the perception that the prophecy of clash of civilizations was starting to come true ${ }^{42}$. After the terrorist attack in Madrid in 2004, the Initiative for the Alliance of Civilization (IAC) was started in 2005. Thus, the IAC emerged as the antithesis of the terror attacks and clash of civilizations.

The leading goals and objectives of the initiative were to determine the solution to centuries long polarization of Islam-Christianity/East-West and the historic environment of mutual prejudice, doubt, fear and disengagement between the Muslim and Western societies by reconciling them. Within the framework of this initiative, Turkey planned projects like Islam and Human Rights Conferences, organized events to fight against Islamophobia and other violations of human rights and freedoms, education seminars for Alliance of Civilization, special seminars and training courses for the religion officials to be appointed in foreign countries, the Great Anatolia Meeting of the world cultures and youth - workshop of alliance of civilization, workshop for the role of media in preservation and conveyance of cultural heritage and in ensuring the intercultural dialogue, European Youth travels Turkey ${ }^{43}$. As seen here, the ruling government tried to reflect the model country image of Turkey to the global public by investing greatly in the initiative.

Thus the government followed the policy of building its new identity by focusing on the theme that Turkey was historically the cradle of different civilizations with its multicultural Ottoman heritage. In this context, the government presented its Muslim democratic identity as a model both to the West and the Muslim World. In addition, JDP leaders wanted to play the role of an actor who can solve the intercultural problems by using mediation based upon its historic background. It could be argued that IAC opened space for Turkey's mediator role between the Islam and Christianity conflicts based on its international image, model country role and its legitimacy provided ${ }^{44}$. IAC as a pub-

41 The UN, "Assembly Proclaims 2001 United Nations year of dialogue among Civilizations, expressing determination to facilitate international discussion", The United Nations, 1998, http://www.un.org/press/en/1998/19981104.ga9497.html.

42 Jefrey Haynes, “Twenty years after Huntington's 'Clash of Civilisations”, 2013, http://www.e-ir. info/2013/02/10/twenty-years-after-huntingtons-clash-of-civilisations/.

43 T.C. MIG, "Türkiye Cumhuriyeti medeniyetler ittifakı ulusal plan 2008-2009", T.C. Dışişleri Bakanlığı, 2008, http://docplayer.biz.tr/2707124-Turkiye-cumhuriyeti-medeniyetler-ittifaki-ulusal-plani-turkiye-cumhuriyeti-medeniyetler-ittifaki-ulusal-plani.html.

44 Nurullah Ardıç, "Civilizational discourse, the 'alliance of civilizations' and Turkish Foreign Policy", Insight Turkey, 16(3), 2014, ss.101-122, s. 105. 
lic diplomacy has a positive effect on its identity and image in both Muslim world and the West. It was also intended that IAC would build the ground for legitimacy and reliability among Muslim and Western worlds. It is suggested that the Initiative for the Alliance of Civilizations contributed to the soft power of Turkey when it was a popular issue in global politics. Hence Turkey included the Initiative for the Alliance of Civilizations among its foreign policy priorities and regarded it to be very significant with respect to the promotion of the country in the world and increasing its visibility. On the other hand, the declaration of Margallo, the Spanish Foreign Minister, which reads "I do not really know what to do with the Alliance of Civilizations" proved that Spain did not give as much importance to the initiative as Turkey had and made the future of the alliance uncertain ${ }^{45}$. The initiative already had very idealistic and utopic objectives and was seriously disrupted as of 2011 and fell off the agenda of the international public opinion after 2012

\section{The Institutional Design of Turkish Public Diplomacy}

JDP leaders perceived the importance of public diplomacy in the 21 st century global politics and instituted to build the public diplomacy and soft power of Turkey for the first time within the framework of the public diplomacy policy at an institutional level in the second period of their government. In this context, new institutions like Presidency of the Office of Public Diplomacy (KDK), Yunus Emre Institute (YEI), The Presidency for Turks Abroad and Related Communities (YTB) were established and the institutions such as the Ministry of Foreign Affairs and Turkish Cooperation and Coordination Agency (TIKA) were reorganized within the context of public diplomacy. As such, these new institutions became the new channel and mechanisms of the Turkish Foreign Policy (TFP) and diversified it with respect to instruments, actors and methods. Furthermore, social and cultural components were added to the TFP, in addition the JDP government made the TFP multidimensional.

Akademik

\section{The Presidency of the Office of Public Diplomacy: The Promotion of New Turkey}

Turkey started to implement the public diplomacy policy very late compared to the Western countries like the U.S., England, and Germany. Although the soft power and public diplomacy activities were being performed under the leadership of TiKA towards the countries of Caucasia and Middle East after the collapse of the USSR in 1991, it was the JDP government that employed the public diplomacy as a policy in 2000s. The main reason for implementing the public diplomacy policy during the JDP government was the desire of the

45 Margallo, "Medeniyetler İttifakı ile ne yapacağımı pek bilmiyorum", Cumhuriyet, 2012, http:// www.cumhuriyet.com.tr/haber/diger/325538/_Medeniyetler_ittifaki_ile_ne_yapacagimi_ pek_bilmiyorum_.html. 
new government to explain itself to the world with respect to its new ideology. The ruling government considered itself to be different from the former governments that had firm focus on secularism, military and security ${ }^{46}$. It was a strategic choice to use public diplomacy policy in order to explain to the world its moderate Islam model with softened secularism that embedded neoliberal capitalist economy. Another essential reason of implementing public diplomacy policy was the ambition of the JDP leaders to make Turkey a regional power and global actor. Therefore, the government established, even if it was late, the Public Diplomacy Coordination Office under the Prime Ministry in January 2010 and started to implement public diplomacy actively at institutional level as a systematic state policy.

The Prime Ministry Public Diplomacy Coordination Office (KDK) was established to provide coordination between the state institutions that perform soft power activities like Ministry of Foreign Affairs, Ministry of Culture, YEI, TIKA and YTB. In addition, KDK drafted and performed public diplomacy programs directly itself. Units for University Programs, Political Communication activities, Media and Promotion Works were established to develop public diplomacy programs. The University Programs Unit carries out Public Diplomacy Panels, Foreign Policy Promotion Programs, Foreign Policy Workshops and Youth programs. The University programs carried out the new Turkish foreign policy. However, university programs were conducted mainly internally which caused the perception of propaganda. Youth programs were made to recruit foreign students and they carried out a successful public diplomacy. Africa and Middle East were determined to be appropriate areas and the young people from these regions were the majority in the youth programs.

Political Communication activities included Country Meetings, Wise People Conferences, Europe Meetings, Panels and International Summit programs. Political communication activities are implemented at an academic level that renders them to be elitist. Inclusion of mainly academic people in communication activities limits the target audience in these kinds of activities. The Media and Promotion Works units conduct Reporters Delegations Program, International Press Information, Culture and Promotion activities. These drew the interest of foreign press in Turkey and ensured first hand and direct information. Within this framework, KDK was established to implement public diplomacy policy to influence the international public opinion. In fact, the primary priority of KDK is, as stated in the established circulation, is to effectively tell the new story of Turkey ${ }^{47}$. It was intended to explain the new identity and Muslim democracy of Turkey particularly with respect to the JDP. This objective was implemented under the soft power concept towards the Muslim countries and people of the Middle East. Therefore, Turkey was finally

46 Ömer Taşpınar, “Turkey: The new model?”, The Brookings Institute, 2012,

47 KDK, "Vision \& Mission”, Kamu Diplomasisi Koordinatörlüğ̈̈, 2016, 
launched as a soft power country to the communities of the region. In addition, KDK employed the activity policy in order to defend the rightfulness of the country before the allegations and problems that it was subjected to. However, this approach turned the institution into a defensive and denial machine. Cemalettin Haşimi, the coordinator of the institution, admitted in an interview by a magazine in 2016 that the office was defensive since its establishment. On the other hand, the government started to operate public diplomacy activities by inaugurating the Yunus Emre Institute, a soft power and cultural diplomacy-oriented institution equivalent to American Culture Centre, British Council and Goethe Institute.

\section{Yunus Emre Institute: Cultural Diplomacy}

Just like KDK, the Yunus Emre Institute (YEI) was established at a later time in 2007 compared to its equivalents in other countries such as Alliance Française, the French culture institute was opened in 1883 and British Council was opened in 1934. Culture institutes are used by countries to conduct cultural diplomacy by promoting their culture, art and values, also to employ and implement their foreign policy in social and cultural areas as well. In this context, YEI was established as a supplementary institute to the Ministry of Foreign Affairs to operate as the social and cultural instrument and actor of the Turkish foreign policy regarding the civil society scope. However, due to the lack of experience in Turkey in the field of cultural diplomacy and lack of sufficient human resources, the Yunus Emre Foundation that was established in 2007 could only operate as the Yunus Emre Institute by 2009. This was due to the fact that it was not known what to do with the institution and the cultural diplomacy. Likewise, YEI could not establish a working strategy since its establishment. Therefore, YEI opened YEI Turkish Cultural Centres in various places of the world upon the requests of those countries. Additionally, it was observed that opening culture centres in the priority areas of the foreign policy was followed as a principle.

The foundational law of the Institute states the objective of the institution is "promoting Turkey, its language, history, culture and art, ... developing friendship with other countries, to increase cultural exchange, offering the related information and documents within and outside the country to the use of the world, providing people who wish to be trained in Turkish language, culture and art with services abroad"48. This phrase reflects the cultural diplomacy of both the institution and Turkey. On the other hand, the Institute was configured above daily politics and parties, since it was established as public foundation and had a state type administration. Within this framework, the board of the trustees, board of management, audit and consultation councils 
were included in the administration of the Institute ${ }^{49}$. In addition, the directors of the public diplomacy Institutes like KDK, TIKA and YTB and particularly the Ministry of Foreign Affairs were included in the administration to execute and coordinated public-culture diplomacy including making the Institute part of the administration mechanism. As cultural centres were opened by the Institute in foreign countries, it employed an NGO-like operative principle instead of as a state-controlled agency. In this aspect, it desired to provide the YEI Turkish cultural centres with an identity of non-governmental identity. Therefore, while the initial method was to open the cultural centres in foreign countries under the framework of embassies, the NGO model was employed as of $2014^{50}$.

The first centre of the Institute was opened in Bosnia Herzegovina on 17 October 2009 with the name "Sarajevo Yunus Emre Turkish Cultural Centre" and the institute started to spread in the Balkans. Likewise, the Minister of Foreign Affairs Davutoğlu said in his speech in the opening of the Sarajevo cultural centre, which was, the first culture centre, that "it is not a coincidence that the first centre is opened in Sarajevo. This is a reasoned decision that we concluded after long thoughts about it" (YEE 2009). We understand that the first area of expansion for the institute was to be the Balkans. Just after that, the second centre was opened in Tiran, the capital of Albania, in 11 December 2009. As of 2014 there are 11 Institute centres in the Balkans: Sarajevo, Tiran, Foynitsa (opening date: 11 October 2011 ), Mostar, Shkodër (20 October 2012), Pristina (26 August 2011), İpek (20 March 2012), Skopje (26 March 2010), Bucharest (14 November 2011) and Constanta (14 November 2011).

After Sarajevo, the Institute opened its first centre in the Middle East. Specifically in Cairo, Egypt in 3 March 2010 and has built 7 centres in the Middle East and Africa as of 2014: Alexandria (27 April 2013), Beirut (23 March 2012), Amman (28 April 2012), Tehran (28 March 2012), Johannesburg (2017), South Africa (December 2012) and Rabat (March 2013). On the other hand, the Yunus Emre Turkish Cultural Centre in Damascus, capital of Syria, which began to operate in 15 December 2010, was closed due to the civil war and deteriorating relations between the two countries. Six centres were opened in Eurasia and Far East: Tbilisi ( 31 May 2012), Baku (2013), Astana (26 May 2010), Kazan (October 2012) and Tokyo (20 October 2011). Eight centres were opened in Europe: Brussels (18 October 2010), London (9 November 2010), Budapest (June 2013), Warsaw (20 June 2011), Berlin (2014), Paris (2014), Amsterdam (2014) and Rome (30 January 2014). In total, 38 centres have been opened in 30 countries in 7 years from 2009 to 2016 since the establishment of the Yu-

49 Yunus Emre Institute Foundation Comission,

50 YEE Strateji, Yunus Emre enstitüsü 2015-2018 stratejik planı, 2015, , s. 11. 
nus Emre Institute ${ }^{51}$. The Institute plans to open cultural centres in cities like Beijing, Washington, New York, Kuala Lumpur, Delhi, Kuwait, Qatar, Dubai, Madrid, and Athens in the years 2017-2018.

The activities of the Yunus Emre Institute and Cultural Centres can be divided into two sections; education activities and culture-art activities. In line with the objective of the Yunus Emre Institute to make Turkish a world language, the basic duty and function of the Yunus Emre Institute Turkish Cultural Centre was determined to be teaching Turkish. The cultural centres initially operated as language courses. The institute aimed to become the sole and leading institution for the teaching of Turkish to foreigners and developed material within this framework as well as the "Turkish Proficiency Exam" (TYS in Turkish origin), which would be an equivalent to TOEFL and IELTS ${ }^{52}$. This would ensure a standard examination with international validity like the Western countries. In addition, the Yunus Emre Institute organizes "Turkish Summer School" every year. It started to be organized in 2010 and covered all expenses of the participants, which amounted to one thousand students from 57 different countries. The students are provided with opportunities to get to know the Anatolian culture and participate in various culture-art activities by visiting various cities of Turkey accompanied by culture guides. Finally, all the groups meet in Istanbul to share their experiences in different cities of Turkey. Attention is paid to keeping Turkish as the language of communication so that the students can improve their speaking skills and establish cultural proximity.

Yunus Emre Institute Turkish Cultural Centres organizes culture-art festivals (film, food festival, traditional art festival), competitions (poem reading, painting, composition, song, drama), clubs (chat, cinema and children club), scientific and academic meetings (conference, symposium, panel, interviews), fairs (language, book, education, promotion and tourism fairs), courses (traditional Turkish hand crafts, music, food, photography, painting and folk dance), concert, exhibition, paper marbling, poem reading, autograph sessions and workshops. At this point, the cultural centres have reached a level of organizing around 500 culture and art events a year. This means that Turkey has learned cultural diplomacy and improved its practice very quickly.

In addition, Yunus Emre Institute carries out six huge projects such as Turcology, Turkish Elective Foreign Language, Rebuilding the Cultural Heritage in the Balkans, Revival of the Traditional Turkish Hand Crafts in the Balkans, 100 Turkey Library Project, 100 Turkey Book Translation Project and Joint Painting Exhibitions ${ }^{53}$. Furthermore, the Yunus Emre Institute developed

51 YEE Faaliyet, Yunus Emre enstitüsü 2014 faaliyet raporu, , s.6.

52 Turkish proficiency exam (TYS).

53 Yunus Emre enstitüsü-projeler. http://eski.yee.org.tr/belcika-bruksel/fr/projects/on-goingprojects. 
various projects to be implemented in 2014-2015 like Turkish Village, Turkey Bookstore, On-Site History Project, Turkish Cage Project, Turkish Education to the Turkish Children in Europe and Distant Turkish Teaching. The Turcology project aims to have a huge number of speakers of Turkish from the Balkans to Caucasia and from Africa to the Middle East. The Turcology project is carried out under cooperation with the universities abroad by sending lecturers from Turkey. Within this framework, Yunus Emre Institute sent around 58 lecturers to 64 universities in nearly 40 countries in academic year of 2014-2015 within the scope of the project ${ }^{54}$. The project also includes various supports, like scholarships to the successful students learning Turkish abroad and allocating scholarships for training young Turcologists. Again within the scope of the Turcology project, support is provided to the different projects on Turkish language, history, art and culture and to activities that promote Turkish language and culture. Beyond this, the Institute follows a strategy to have Turkish language be taught as an elective foreign language in the schools of the host countries where the cultural centres are located. In this context, the Ministries of Education of the cantons of Hersek-Neretva, Bosna-Podrinye, Zenica-Doboj of the Federation of Bosnia Herzegovina issued a decision to teach Turkish as the second elective language from $6^{\text {th }}$ grade to $13^{\text {th }}$ grade in the primary and secondary schools in the academic year of 2012-201355. In addition, Turkish is taught as elective foreign language in Georgia, Morocco, Tunis and Algeria.

With project of rebuilding cultural heritage in the Balkans, work has been carried out to repair, maintain, preserve, and transfer to the digital media, Ottoman manuscripts that were destroyed during different wars in seven countries in the Balkans (Bosnia-Herzegovina, Macedonia, Albania, Kosovo, Serbia, Monte Negro, and Croatia). This aims to re-strengthen the historic ties of the Balkans with Turkey ${ }^{56}$. The project of reviving the traditional Turkish handcrafting in the Balkans aims to revive the forgotten arts in the region. Finally, Turkey Libraries Project aims to establish 100 Turkey libraries all around the world.

\section{The Presidency for Turks Abroad and Related Communities (YTB): Diaspora diplomacy}

Turkey started to engage in diaspora diplomacy for the first time during the JDP rule by opening the YTB. It was decided during the JDP government that

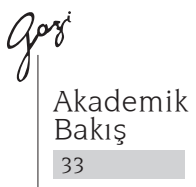

Cilt 11

Sayı 23

Kış 2018

54 Hayati Develi, "Yunus Emre enstitüsü başkanı Prof. Dr. Hayati Develi: Hedefimiz yurtdışında 100 kültür merkezi", Edebiyat Haber, 2015, http://www.edebiyathaber.net/yunus-emreenstitusu-baskani-prof-dr-hayati-develi-hedefimiz-yurtdisinda-100-kultur-merkezi/.

55 "Türkçe Saraybosna da seçmeli ders oldu", Hürriyet, 2013, http://www.hurriyet.com.tr/turkcesaraybosna-da-secmeli-ders-oldu-24682603.

56 Bülent Sarper Ağır ve Arman M. N., "Turkish Foreign Policy towards the Western Balkans in the Post-Cold War Era: Political and Security Dimensions", in Turkey's Foreign Policy and Security Perspectives in the 21 st Century. Sertif Demir (ed.), Roca Raton: BrownWalker Press, 2016, ss. 143-166. 
the need to implement a state policy towards the Turkish diaspora was an issue of debate as "Foreign Turks" in the Turkish foreign policy ${ }^{57}$. As the concept of foreign Turks has a negative connotation with imperialistic expansion, the government preferred to use the concepts of Turks Abroad and Related Communities for the Turkish diaspora. The opening justification of the institution and its area of duty are based upon the phrase in the 62nd article of the constitution which reads "the state takes the necessary measures to provide the family union, education, cultural needs and social securities, connection with the homeland of the Turkish citizens working in foreign countries and to help them in their return to the homeland"58. Thereupon, the area of duty of YTB was determined in the 1st Article of the law of establishment as "carrying out works regarding our citizens living abroad, to produce solutions to their problems; carrying out activities for these communities to develop social, cultural and economic relations with the cognate and related communities"59. Hence, the target audience of the Directorate is the Turkish citizens living abroad, cognate and related communities. Its vision was determined to be "looking out for all Turks wherever they are". The agency acts on this principle and aspires to find solutions to the problems of cognate and related communities, to strengthen their ties with Turkey and to protect their cultural values.

In order to realize above mentioned vision and mission, YTB organized its corporate organization in five different areas of work: Overseas Citizens, Cognate and Related Communities, NGOs, Law and International Students ${ }^{60}$. The main target audience of the Overseas Citizens unit was the 6 million Turkish citizens living throughout the world. This made the core diaspora population of Turkey and YTB focus. Besides, the cognate and related communities with around 250 million people are the other potential diaspora of Turkey. The overseas citizens unit carries out activities for protection of the overseas citizens against assimilation, to guarantee their existence in their countries, to protect their social and cultural links with Turkey. Therefore, "Overseas Citizens Advisory Board" was created in December $2012^{61}$. Consequently, the board consists of 80 members representing 19 countries and regions and it is the "Turkish Diaspora Assembly" as stated by Bekir Bozdağ, then the Deputy Prime Minister. More than that, YTB plans to increase the number of foreign

57 Mustafa Aydın, "Kafkasya ve Orta Asya'yla ilişkiler”, in Türk Dış Politikası: Kurtuluş Savaşından Bugüne Olgular, Belgeler, Yorumlar. Baskın Oran (ed.), İstanbul: İletişim Yayınları, 2008, s. 370.

58 YTB Kanun, Yurtdişi Türkler ve akraba topluluklar başkanliği teşkilat ve görevleri hakkinda kanun, 2004, Resmi Gazete, 6/4/2010.

59 a.g.e.

60 YTB Teşkilat, Yurtdışı Türkler ve akraba topluluklari başkanliği teşkilat. https://www.ytb.gov. tr/teskilat.php.

61 YVDK, Yurtdışı vatandaşlar danişma kurulu yönetmelik", http://www.resmigazete.gov.tr/eskiler/2012/07/20120721-19.htm 
missions to 228 as of 2016 and to 250 between 2016 and $2017^{62}$. The board pursues to develop and organize a social dialogue environment with the Turkish citizens living abroad. The Cognate and Related Communities unit aspires to develop and strengthen the historic, cultural, social, and economic ties of Turkey with these communities and carries out related activities to these goals.

Furthermore, the NGOs unit carries out activities to support the organization of the overseas citizens under NGOs in their current countries and to increase the effectiveness of these organizations. The unit attempts to ensure they retain representation in the public and country politics through NGOs and it develops projects to encourage organized participation in the politics of their current living countries as part of civil society organizations. The reason for following an NGO-like strategy is that the global system and politics have operated through civil society and NGOs as of 1990s. When we look at the conditions of the overseas Turks with respect to civil society organizations, we understand that they have a high potential even if they are independent from each other. Just in Germany alone, there are around 2000 NGOs with association status carrying out works for the foreign citizens. The biggest NGO in Germany is DITIB (Religious Affairs Turkish Islam Union) that combines 896 associations under a sole foundation ${ }^{63}$. The unit aspires to help the Turkish diaspora by organizing the current potential as NGOs and it plans to create the Turkish World Diaspora Council and Diaspora Congresses through the union of the NGOs. In addition, this unit carries out capacity development training programs to develop the capacities of current NGOs and to teach different ways of organizing the overseas Turks under NGOs. The unit also organizes social dialogue programs to help establish regular communication network among the Turkish NGOs. The law unit organizes international law training programs to produce solutions to the legal problems overseas citizens may be having and to provide awareness of their legal rights. The major public diplomacy activities of the agency can be listed as being, an overseas young leaders program, leadership education programs, cultural exchange and education programs and cultural tour camps.

In addition to these activities, YTB combined different higher education scholarships that were granted to international students by various state agencies under an individual foundation called "Turkey Scholarships". The first implementation of the Turkey Scholarships was done in 2012, and can be considered as one of the greatest public diplomacy activities of Turkey and equivalent to the Fulbright scholarship in the U.S. Likewise, the scholarships granted to foreign students by several state agencies like Turkish Council of Higher

62 Bekir Bozdağ, Yurt dışı vatandaşlar danışma kurulu toplantısı", Haberler, 2013, http://www. haberler.com/yurt-disi-vatandaslar-danisma-kurulu-toplantisi-4739308-haberi/.

Akademik Bakış 35 Cilt 11 Sayı 23 Kış 2018 
Education (YÖK), the Scientific and Technological Research Council of Turkey (TUBITAK) and TíKA used to be independent from each other and without any programs under public diplomacy. However, since 2011, YTB guides these scholarships to make Turkey a base of education through the public diplomacy perspective. These scholarships are channelled into categories according to the tendency of the Turkish foreign policy usually towards Turkish speaking countries (Central Asia), Balkans, Africa, Harran (Middle East), Estuary (South Asian countries), Bosporus (India, China, Japan, South Asia, Brazil) and Anatolia (Afghanistan, Somali). Stunningly, the demand for Turkey scholarships increased rapidly from 2003 to 2016. Initially, YTB had a demand for scholarships around 90 thousand annually, while there were 155 thousand applications from 182 countries for the Turkey Scholarships between 2015 and $2016^{64}$. Scholarships were granted to more than 50 thousand students between 2012 and 2016. In conjunction with the increase in scholarships, the number of foreign students in Turkey increased as well. Thus, Turkey entered the international education market as a new player.

In conclusion, YTB operates like a "Diaspora Ministry" for the purpose of building a lobbying arm globally for Turkey. Likewise, the Overseas Citizens Advisory Board (YVDK) continues to operate as "the Turkish Diaspora Assembly" from 2012. Turkey wants to build a Turkish lobby using the Turkish diaspora such as the Jewish and Armenian lobbies have been created by respective countries instead of depending on others to lobby for it. From the perspective of the Turkish foreign policy, Turkey was incomplete and weak until now in the fields of diaspora and lobbying. For instance, Turkey asks for help from Israel and Greek lobbies from time to time depending on the matter as it does not have a lobby in Washington D.C. However, the country was in hard positions especially recently when its relations with these two lobbies broke down. Therefore, the need of developing diaspora and lobbying politics of its' own is critical for the Country. The diaspora is vital component for public diplomacy and it opens areas in other countries. It is especially important in international

Akademik relations as respect to lobbying roles and it can serve as leverage. In this context, it could be argued that Turkey started to follow the diaspora policy very late with YTB being established in 2011. As can be understood from the above activities of the institution, it is believed that the diaspora policy of Turkey are organizing the overseas Turkish citizens, cognate and related communities and to make use of them, particularly in respect to lobbying activities. It is suggested that Turkey aims to reach its' global diaspora community with it so that it can use it as soft power in its international relations.

64 “Türkiye bursları'na 155 bin aday başvurdu”, Hürriyet, 2015, http://www.hurriyet.com.tr/ turkiye-burslarina-155-bin-aday-basvurdu-28667790. 


\section{Turkish Cooperation and Coordination Agency (TIKA): Foreign Aid and Humanitarian diplomacy}

Turkey adopted public diplomacy as a foreign policy in 2000s; however, the soft power policy was implemented at institutional level in 1990s for the first time with TiKA. After the collapse of Soviets in 1991, Turkey established the agency in 1992 as an institution to create soft power and to enlarge its influence in the Balkans, Caucasia and Central Asia ${ }^{65}$. TiKA was initially established as a technical aid agency and its purpose was to remove the separation created during the Soviet rule by reviving the socio-cultural and historic ties between Turkey and those related communities where Turkish language was spoken. For this purpose, TiKA realized cooperation projects in the field of economics, trade, socio-cultural areas and education. Further, Turkey provided the agency with great amounts of loans and grants for the development of the countries in the region it was targeting. This way TiKA served as a soft power institution that increases its effectiveness by filling the power vacuum that emerged in Balkans, Caucasia and Central Asia after USSR.

Under the JDP government, TIKA was reorganized in 2011 within the framework of public diplomacy. Firstly, the word "development" in the name of the agency was replaced with the word "coordination" and the principle of coordinated work was done with the other public diplomacy institutions ${ }^{66}$. In addition, the agency was supposed to work in coordination with the equivalent international organizations. To continue, the agency, which used to operate as a technical aid organization, was to adapt to the conditions of the current period and work on project base operations. On that account, foreign grant aids were transformed to projects instead of the old way of giving cash payment. Therefore, the organization and overseas coordination structure of the agency was re-structured. Accordingly, the organization, and the structuring of the agency occurred in four regions in accordance with areas of influence Turkish foreign policy had, that is: Central Asia and Caucasia, Balkans and Eastern Europe, Middle East and Africa, East and South Asia, Pacific and Latin America Departments. TiKA previously had focused on the Balkans, Caucasia and Central Asia but during the JDP government its focus was transformed in line with the expansions of JDP foreign policy towards the Middle East, Africa and Latin America. This made the geographic activity of TiKA a global one considering the areas it covered. The agency had 12 foreign offices in 2002 and this number was increased to 50 in 2016 as an extension of the regional expansions in foreign policy. Additionally, it was Central Asia, which was the number one recipient of development aid, but now Africa and Central Asia have replaced

65 TiKA Tarihçe, “TiKA tarihçemiz", 2016,

66 TíKA Mevzuat, Türk işbirliği ve koordinasyon ajansı başkanlığının teşkilat ve görevleri hakkında kanun", TiKA, 2011, http://www.resmigazete.gov.tr/eskiler/2011/11/20111102-1.htm.

Akademik Bakış 37 Cilt 11 Sayı 23 Kış 2018 
it. According to the 2014 data, the project expenditure of TiKA for the Middle East and Central Asia reached USD 369 million $^{67}$. The money that the agency spent on global projects in 2014 reached USD 3.6 billion $^{68}$. The countries that benefitted the most from the aid were Syria, Tunisia, Palestine, Somali, Sudan, Afghanistan, Egypt and Bosnia Herzegovina.

Upon the reorganization of TiKA, its fields of activity started to include various sectors like social infrastructure services, education, health, agriculture, population, water, administrative and civilian infrastructure services, and economic infrastructure services. The number activities done by the agency in the different areas mentioned reached 2 thousand projects between 1992-2002, while this number was more than 11 thousand between 2002-2014 this means that an increase of $96 \%$ occurred in the official development aid ${ }^{69}$. Moreover, the projects realized by the agency covered 28 countries between 1992-2002 while this number was more than 140 countries in years between, 2003-2014. In this way, TiKA became a prestigious institution for Turkey, when it came to implementing foreign aid and humanitarian diplomacy at a global level. Besides, TiKA contributed greatly to the international prestige of Turkey and gave it an image of aid providing country instead of an aid receiving country. Thanks to these activities of the agency, the UN World Food Program announced Turkey as a rising donor country. In addition, TiKA became a milestone of the policy of Turkey when it came to becoming a global actor. Likewise, by diversifying the Turkish foreign policy, the agency became both an indispensable instrument of foreign policy and the main institution for providing soft power for Turkey. In the final analysis, the activities of TiKA and its existence at a global level increased affection and sympathy for Turkey and ensured that it was viewed as a formidable global actor.

\section{The Restructuration of the Ministry of Foreign Affairs}

The Ministry of Foreign Affairs that had implemented conventional diplomacy was restructured by a new organization law adopted after an interval of 16 years in order to adapt to the changing global system and transforming diplomacy. Accordingly 10 new units were established within the ministry ${ }^{70}$. Those related to public diplomacy were Deputy General Directorate for Cultural Diplomacy, General Directorate for Information, Public Diplomacy Unit, Public Communication Department, Diplomacy Academy Department and Information Technologies Department, While, The General Directorate for Overseas

67 TiKA Rapor, TiKA Türkiye kalkınma yardımları 2014 Raporu, http://www.tika.gov.tr/upload/ publication/KYR\%20\%202014.PDF, s.14.

68 a. g. e. S. 9

69 TíKA Dünyası, “TiKA dünyası”, 2013. , s. 6.

70 Ü. Ünsal, "T.C. Dışişleri Bakanlığı ve yeni teşkilat kanunu”., Türk Dış Politikası: Kurtuluş Savaşından Bugüne Olgular, Belgeler, Yorumlar, Baskın Oran (ed.), İstanbul: İletişim Yayınları, 2013, s. 240. 
Promotion and Cultural Relations was established as the unit responsible for cultural diplomacy. Deputy General Directorate for Cultural Diplomacy was also established. The objective of this unit was to promote the country via cultural activities; another duty was to provide coordination and diplomatic assistance for the Yunus Emre Institute and the overseas Yunus Emre Institute Turkish Culture Centres. Furthermore, the unit conducts the bilateral cultural agreements and exchange program agreements and under the JDP rule it extracted new cultural cooperation and exchange agreements with 29 countries in 10 years. In addition, the directorate organizes and supports comprehensive mutual activities abroad like "Culture Years", "Turkish Culture Weeks", "Turkish Culture Days", "Turkish Cinema Days" and "Turkish Film Weeks".

The duty of the General Directorate for Information was to carry out relations with media, to ensure communication with foreign public and to plan and execute the activities in public diplomacy as direct to by the units of the ministry for public diplomacy. What is more, this unit had the duties of press information and public enlightenment, promotion of foreign policy to the national and international press. The Department for Diplomacy Academy conducts appreciated works to make the Turkish Ministry of Foreign affairs a centre of interest and attraction with its "Foreign Young Diplomats Education Program" for foreign diplomats. Likewise, cooperation agreements were signed in the last 10 years between 38 countries and the Diplomacy Academy and 17 cooperation protocols and exchange agreements were signed in 2012 alone. The Department of Information Technologies carries out duties that make the ministry effective on social networks like Facebook, Twitter and YouTube in various languages.

\section{TRT World and Anadolu Agency: Media Wars}

TRT is a state television channel that carries out activities in the communication and information field of public diplomacy, and it was reorganized to run like CNN or BBC by way of establishing TRT World. The reason for this was to increase Turkey's power of mass communication instruments and new social media tools in global politics particularly during 2000s. In addition, states had started to have an increasing tendency to use media as a diplomatic leverage and even as a weapon to ensure the support of the international public opinion when it came to international relations. Beyond that, the fact that the global politics turned to an intellectual and ideological war caused different states to apply a new structuring in the field of media. In this context, CNN in USA, BBC in Britain, Russia Today in Russia, CCTV in China, DW in Germany and Al-Jazeera in the Arab World were already well positioned to wage these global media wars. Therefore, Turkey entered the international media wars environment with institutions like TRT World and Anadolu Agency.

\begin{tabular}{l|l} 
Gor' \\
Akademik \\
Bakış \\
Cilt 11 \\
Say1 23 \\
Kiş 2018 \\
\end{tabular}


The understanding that Turkey needed global media instruments to help and explain and defend its own policies, like the West had been doing, developed within the framework of public diplomacy under the JDP government. The international channels of TRT have become the voice of Turkey regarding to its country story as an international instrument for political communication. Thus, TRT serves the function of being a communication bridge for Turkey with the world. These international channels are the face and images of Turkey as it was opening to the world and they were established as the main instrument of establishing a public opinion for the benefit of the country. Hence, in public diplomacy, the state used global TV channels broadcasting in different cultures to create public opinion and gain the support from the international community. Therefore, TRT has progressed towards becoming the indispensable communication instrument of the Turkish public diplomacy and one of the most effective tools to build Turkey as an attractive country and to build a positive perception of it.

\section{Conclusion: Syrian Crisis and the Fall of Soft Power and Public Diplomacy}

Turkey was able to have a successful public diplomacy and soft power policy between 2003 and 2013. During this decade, JDP leaders initially achieved their goal of drawing the attention of the world by promoting an admirable marketing of the foreign policy they implemented. The government argued that they followed a soft power-based policy to develop socio-cultural and trade relations by leaving security-based and hard power-based politics of the former governments behind. The JDP leaders launched their foreign policy in to the world by using various rhetoric and discourses. Firstly, they claimed that Turkey was no more a front country like it was during the period of Cold War but a central country with its historical, cultural and geographical ties. Besides, Foreign Minister Davutoğlu declared that Turkey's objective was to become a regional power and a global actor by using heroic discourses such as proactive and rhythmic diplomacy, zero-problem policy and multi-dimensional foreign policy $^{71}$. Thus, JDP leaders designed the Turkish foreign policy around various peculiar metaphors and rhetoric to draw an image of soft power to the rest of the world. However, the Middle East-oriented soft power and public diplomacy policies of Turkey were blocked by the Arab Spring, the Syrian crisis and certain policies implemented from 2011 on.

Historically, the relationship between Syria and Turkey had recurring problems since the establishment of the Republic of Turkey due to border and water issues. The normalization process between Turkey and Syria first started with Syria's declaration of October 1998 that expelled Abdullah Öcalan, the leader of the PKK (Kurdistan Workers' Party) terrorist organization that

71 Ahmet Davutoğlu, a. g. m. s. 82. 
conducts terrorist actions against Turkey. Thereafter, the JDP took power, and closer relations begun between the two countries from 2003 on. In August 2008 , the leaders of the two countries were so close that they had a joint vacation in Bodrum. Additionally, a high level council for strategic cooperation was established between the two countries and the two countries had almost joint cabinet meetings at times. The relationship between the two countries in years between 2003 and 2011 was often referred to as honeymoon and golden age in the academic circles and the press. However, during the Arab Spring process, the Syrian crisis emerged when the Syrian President Esad started to fight with his own people instead of conducting reforms. During this time, the Minister of Foreign Affairs Davutoğlu had frequent trips to Syria and made attempts to persuade Esad to heed the people's demands and to reform instead of fight his own people. However, these attempts by Turkey failed and the government changed its Syrian policy after the emergence of civil war in Syria and the mass killing of people by Esad. The Syrian policy of Turkey was obsessively built on having Esad leaving ${ }^{72}$. In this framework, Turkey started to support the opponents of the Esad regime in military and logistic aspects while the relations of the two countries turned from soft power to hard power and even to some war aspects ${ }^{73}$.

Syria was the pilot country of the model country and soft power policy of Turkey. However, the Syria crisis halted the rise of Turkey as a soft power in the Middle East and in the world through its policy since 2003, it also caused Turkey to abandon its soft power policy in foreign policy and turn to hard power. In this context, the Syrian crisis brought to the end the soft power and public diplomacy policy of the government. The Syrian crisis did not only break the relationship between the two countries, but also Turkey had to start a military operation called the Euphrates Shield in Syria after the mass killing of Syrian people by Esad. Beyond that Turkey started for the first time to provide military aid to the opponents in other countries in their fight against the regime. Thus, the Syrian crisis made Turkey again a front country like it had been during the Cold War era. Beyond that, the multidimensional foreign policy has been blocked since 2013 because of the Arab Spring and Syrian crisis. The relations of Turkey with its neighbours started to deteriorate, foreign missions and ambassadors were called back and Turkey became alone in the world, particularly in its own region. This condition that Turkey was facing was explained in August 2013 as "precious loneliness" by İbrahim Kalın, the diplomacy chief advisor of the President and then the speaker of the President's office ${ }^{74}$.

72 D. Ertuğrul, “Türkiye Dış Politikası için bir test: Suriye krizi”, TESEV, 2015, http://tesev.org.tr/ wp-content/uploads/2015/11/Turkiye_Dis_Politikasi_Icin_Bir_Test_Suriye_Krizi.pdf, s. 2.

73 C. Phillips, "Into the quagmire: Turkey's frustrated Syria policy", Chathamhouse, 2012, , s. 2.

74 İbrahim Kalın, "Dış politikada 'değerli yalnızlık' dönemi”, Hürriyet, 2013, http://www.hurriyet. com.tr/dis-politikada-degerli-yalnizlik-donemi-24553602.

Akademik Bakış 41 Cilt 11 Sayı 23 Kış 2018 
Since 2003, the Turkish foreign policy under JDP leadership has been multidimensional from the Middle East to Africa, from Europe to Latin America. It started to be limited within the Middle East and even Syria as of 2013. In other words, the strategic depth of Foreign Minister Davutoğlu was contained within the Syria policy alone. This referred to the end of the multidimensional period of the Turkish foreign policy. The Syrian crisis ended both the Arab Spring and the soft power of the Turkish foreign policy. The most tragic point is the fact that the ambition for leadership of JDP policymakers in the Middle East and the discourse that the Muslim world would rise up under the leadership of Turkey failed. The Syrian crisis ended the moderate Islam policy of the U.S that was aimed at the transformation of the radical movements and administrations in the Middle East and the model country policy of Turkey, while it also caused the emergence of a conflictual dynamics between the Muslims in the region. On the other hand, the Syrian crisis caused Turkey to quarrel with almost all its neighbours except Saudi Arabia and Qatar.

\section{REFERENCES}

AĞIR, B. S. and Arman, M. N., "Turkish Foreign Policy towards the Western Balkans in the Post-Cold War Era: Political and Security Dimensions", in Tur key's Foreign Policy and Security Perspectives in the 21st Century. Sertif Demir (ed.), Roca Raton: BrownWalker Press, 2016.

AĞIR, B. S., Non-traditional security issues of the Western Balkans: Actors, causes and implications. Turkish Yearbook of International Relations, 45, 2014, 65-91. AK PARTI. The new Turkey contract 2023.

AKDOĞAN, Y., AK parti ve muhafazakar demokrasi. İstanbul: Alfa Yayınları, 2004.

ALTUNIŞIK, M. B., Turkish foreign Policy in the $21^{\text {st }}$ Century. 2011, .

ARDıç, N., Civilizational discourse, the 'alliance of civilizations' and Turkish Foreign Policy. Insight Turkey, 16(3), 2014, ss. 101-122.

ATASOY, S., The Turkish example: A model for change in the Middle East?. Middle East Forum, 2011, .

AYATA, B., Turkish Foreign Policy in a changing Arab World: Rise and fall of a regional actor?. Journal of European Integration, 37, 2014, ss. 95-112.

AYDıN, M., Kafkasya ve Orta Asya'yla ilişkiler. in Türk Dış Politikası: Kurtuluş Savaşından Bugüne Olgular, Belgeler, Yorumlar. Baskın Oran (ed.), İstanbul: İletişim Yayınları, 2008.

ARAS, B., Davutoğlu era in Turkish Foreign Policy, SETA Policy Brief, 32, 2009, http://arsiv.setav.org/ups/dosya/20875.pdf.

BOZDAĞ, B., Yurt dışı vatandaşlar danışma kurulu toplantısı", 2013, .

CARROL, T. P., Turkey's justice and development party: A model for democratic Islam?. The Middle East Intelligence Bulletin, 2004, . 
DAVUTOĞLU, Ahmet, Turkey's Foreign Policy vision: An assessment of 2007. Insight Turkey, 10(1), 2008, ss. 77-96.

DAVUTOĞLU, Ahmet, “Davutoğlu: Ortadoğu'ya bataklık dedirtmeyeceğiz”, 2014, . DEİK. (2016). Deik iş konseylerinde yeni dönem başliyor. .

DEVELI, Hayati, "Yunus Emre enstitüsü başkanı Prof. Dr. Hayati Develi: Hedefimiz yurtdışında 100 kültür merkezi”, Edebiyat Haber, 2015, .

DITIB, Hakkında. 2016, .

EROL, M. S., 11 Eylül sonrası Türk Dış Politikasında vizyon arayışları ve Dört Tarz-1 Siyaset. Akademik Bakış, I(1), 2007, ss. 33-55.

ECONOMIST, (2010). The great mediator. 2010, The Economist, .

EKONOMI BAKANLIĞI, Serbest ticaret anlaşmalarına ilişkin genel bilgi. 2014, . EKŞI, Muharrem, The Rise and Fall of soft Power in Turkish Foreign Policy: The rise and fall of the 'Turkish Model' in the Muslim World, Saarbrücken: LAP Lambert Academic Publishing, 2016.

EKŞI, Muharrem, AK Parti döneminde Ortadoğu'da Türk-Amerikan ilişkilerinin Jeokültürel Ekseni: İslami kimlik. Gazi Akademik Bakış, 9 (18), 2016, ss. 59-77. ERTUĞRUL, D., Türkiye Dış Politikası için bir test: Suriye krizi. TESEV 2015, .

GÜLSÜM, N., AK Parti modeli dünya için şans", Yeni Şafak 2015,

GÜRZEL, A., “Turkey's role as a regional and global player and its power capacity: Turkey's engagement with other emerging states"., Rev. Sociol. Polit, 22(50), 2014, ss. 95-105.

HALE, W., "Christian Democracy and the AKP: Parallels and contrasts", Turkish Studies, 6(2), 2005, 293-310.

HAYNES, J., Twenty years after Huntington's ‘Clash of Civilisations. 2013, .

HUNTINGTON, S., "The clash of civilizations", Foreign Affairs, 27(3), 1993, 22-49. HÜRRIYET. Türkçe Saraybosna da seçmeli ders oldu", Hürriyet, 2013, .

HÜRRIYET. “Türkiye bursları'na 155 bin aday başvurdu”, Hürriyet, 2015, .

IDIZ, S., Will Islamic world accept Turkey's leadership?. Al Monitor, 2016, .

JPOST, "Hamas: Erdogan's victory is a victory for Palestine”, Jpost, 2015, .

KALıN, İ., Dış politikada 'değerli yalnızlık' dönemi”, Hürriyet, 2013, .

KDK, "13 yılda 65 yeni temsilcilik: Türkiye'nin yurtdışındaki temsilcilik sayısı 228'e çıktı”. KDK, "Yüksek Düzeyli İşbirliği Mekanizmaları”, .

KDK, "T.C. Başbakanlık kamu diplomasisi koordinatörlüğü”, .

KDK, "Vision E Mission", .

KUJAWA, K., "Turkey and democratization in the Arab World: Between an inspiration and a model". PISM Policy Paper, 2011, . 
LÜTEM, Ö. E. "Türkiye-Ermenistan ilişkilerinin güncel durumu”, Yeni Türkiye, 60, 2014, ss. 1-91.

MARGALLO, "Medeniyetler İttifakı ile ne yapacağımı pek bilmiyorum",

MFA, Protocol on development of relations between The Republic of Turkey and The Republic of Armeni, 2009,

MFA. Turkey- GCC high level strategic dialogue meeting of Ministers of Foreign Affairs to be held in İstanbul. http://www.mfa.gov.tr/turkey-gcc-high-level-strategic-dialogue-meeting-of-ministers-of-foreign-affairs-to-be-held-inistanbul.en.mfa.

MOUBAYED, S., “Turkish-Syrian relations: The Erdoğan legacy”. SETA DC Policy Brief, 2008,

NASUH U., Türkiye'nin yeni Orta Doğu yaklaşımı. Bilig, 52, 2010, ss. 147-180.

NATIL, İ., Turkey's Foreign policy challenges in the Syrian crisis. Irish Studies in International Affairs, 27, 2016, ss. 1-10.

ORAN, B., Türk Dış politikası: Kurtuluş savaşından bugüne olgular, belgeler, yorumlar, İstanbul: İletişim Yayınları, 2013.

PHILLIPS, C., "Into the quagmire: Turkey's frustrated Syria policy", Chathamhouse, 2012,

SAMBUR, B., "The great transformation of political Islam in Turkey: The case of justice and development party and Erdogan", European Journal of Economic and Political Studies, 2(2), 2009, ss. 117-127.

T.C. MIG. Türkiye Cumhuriyeti medeniyetler ittifakı ulusal plan 2008-2009, .

TAŞPıNAR, Ö., "Turkey: The new model?", The Brookings, 2012, .

The UN, Assembly Proclaims 2001 United Nations year of dialogue among Civilizations, expressing determination to facilitate international discussion. TIKA, TiKA dünyası 2013. .

TIKA, TIKA koordinatörlükler. .

TiKA, “Türk işbirliği ve koordinasyon ajansı başkanlığının teşkilat ve görevleri hakkında kanun", http://www.resmigazete.gov.tr/eskiler/2011/11/20111102-1.htm. TİKA, TíKA Türkiye kalkınma yardımları 2014 raporu. .

TIKKA, TiKA tarihçemiz. .

TRAUB, J., "Turkey rules”, The New York Times, 2011, .

TRTHABER, “Türkiye, insani yardımda lider ülke”, TRT Haber, 2016, .

TÜR, Ö., Economic relations with the Middle East under the AKP-Trade, business community and reintegration with neighboring zones. Turkish Studies, 12(4), 2011 , ss. 589-602.

TYS, Turkish proficiency exam (TYS). .

UNAOC, "Who we are", . 
ÜSTUN, K. and Kanat, K., “US- Turkey relations: Arab Spring and the search for model partnership", SETA, 2012, .

ÜNSAL, Ü. "T.C. Dışişleri Bakanlığı ve yeni teşkilat kanunu”, Türk Dış Politikası: Kurtuluş Savaşından Bugüne Olgular, Belgeler, Yorumlar, Baskın Oran (ed.), İstanbul: İletişim Yayınları, 2013.

VOLKER P., Turkey role in the Middle East: An outsider's perspectives. Insight Turkey, 12(4), 2017, ss.1-8.

YEE, Yunus Emre vakfi kanunu, .

YEE, Saraybosna Yunus Emre Türk kültür merkezi açildi. .

YEE, Foundation Comission. .

YEE, Yunus Emre enstitüsü 2014 faaliyet raporu, .

YEE, Yunus Emre enstitüsü-projeler. .

YEE, Yunus Emre enstitüsü 2015-2018 stratejik planı, .

YESILYURT, N. ve Akdevelioglu, A., "AKP döneminde Türkiye'nin Ortadoğu Politikası", AKP Kitabı: Bir Dönüşümün Bilançosu, Uzgel, İlhan ve Duru, Bülent (ed.), Ankara: Phoenix, 2009.

YTB, Yurtdişi Türkler ve akraba topluluklar başkanliği teşkilat ve görevleri hakkinda kanun. Resmi Gazete, 6/4/2010. .

YTB, Yurtdışı Türkler ve akraba topluluklari başkanliği teşkilat. .

YVDK, Yurtdışı vatandaşlar danişma kurulu yönetmelik. .

ZANOTTI, J., “Turkey: Background and U.S. relations”, US Congressional Report, 2014, . 